\title{
EVALUATION OF DIFFERENT PROTEIN PRECIPITATES OF A WILD MUSHROOM, GANODERMA LUCIDUM FOR ANTIBACTERIAL ACTIVITIES AGAINST HUMAN PATHOGENIC BACTERIA
}

\author{
SUNDARAMOORTHY MARIMUTHU*, SABARIMANIKANDAN MAHENDRAN
}

Department of Zoology, Rajah Serfoji Government College, Thanjavur, Tamil Nadu, India. Email: drmsundartnj@gmail.com

Received: 23 April 2019, Revised and Accepted: 01 June 2019

ABSTRACT

Objective: The objective of the present study was to isolate different antibacterial protein precipitates from Ganoderma lucidum against human pathogenic bacteria and to evaluate suitable precipitating agent.

Methods: The acid extract was prepared from the aqueous solution of the test mushroom. From separate aliquots of acid extract, antibacterial proteins were precipitated using five different concentrations (10-50\%) of ammonium sulfate solutions, 10\% trichloroacetic acid (TCA), $80 \%$ ethanol and methanol - Chloroform mixture (2:1 ratio). Protein quantification was performed in each stage of purifications. The as-prepared protein precipitates were subjected for antibacterial and hemolytic assays for identification of the active protein precipitate, which in turn was also checked for minimum inhibitory volume (MIV) for all test organisms.

Results: The quantity of each protein precipitated by different protein precipitating agents from the acid extract of the test mushroom was found in the range of 2.3-4.8 mg/g wet.wt. Although all the precipitates showed different levels of antibacterial capacities, $10 \%$ TCA precipitate was considered as active protein as it yielded the maximum amount of protein (4.8 mg/g.wet.wt) as well as it exhibited burly bactericidal activities at lower volumes of protein solutions subjected ( 6.3 and $3.2 \mu \mathrm{l})$ on all bacterial strains tested with less hemolytic effects.

Conclusion: The protein precipitated by $10 \%$ TCA from the acid extract of the test mushroom could be developed as a drug candidate for treating infectious diseases caused by pathogenic microbes in human.

Keywords: Mushroom, Acid extract, Trichloroacetic acid, Minimum inhibitory volume, Hemolytic assay.

(C) 2019 The Authors. Published by Innovare Academic Sciences Pvt Ltd. This is an open access article under the CC BY license (http://creativecommons. org/licenses/by/4. 0/) DOI: http://dx.doi.org/10.22159/ajpcr.2019.v12i7.33714

\section{INTRODUCTION}

The abuse of antibiotics results in the selection of multi-resistant bacterial strains and it is challenging to treat their infections. It is well-known evidence that Methicillin-resistant Staphylococcus aureus is resistant to multiple antibiotics rather than methicillin. Likewise, the bacteria Klebsiella spp. and Escherichia coli presentresistanceto the third generation of cephalosporins [1,2]. To treat such infections, phytochemicals are widely recognized as good alternatives to classical antibiotics due to the fact that they are derived from natural sources existing in our environment. For instance, a recent study shows that the ethanolic extract of Trachyspermum ammi seed has strong antibacterial activity against Shigella spp. [3]. However, yet there is not a proven record for not developing resistant strains when treating infectious diseases by phytochemical drugs. For the past few decades, the small molecules of proteins (1-100 kDa) named antimicrobial proteins/peptides (AMPs) isolated from various parts of living entities have been extensively acknowledged as natural antibiotics as they assassinate the organism by direct cytolysis. This typical killing mechanism involves ionic interaction and never leads the organisms to develop resistance. They exhibit a broad spectrum of antimicrobial activities against bacteria, fungi, and viruses [4-10].

Our group [11-13] has also substantiated the presence of antibacterial proteins in different organs such as liver, heart, kidney, and muscles of fish, goat, and chick. Among these organs, only the heart tissues of all animals exhibited strong antibacterial activities against various human pathogenic bacteria. However, the bulk preparation of AMPs from such tissues could be a hard task due to the inconvenience involved in collection of such organs in kind enough quantities from slaughterhouses.

Mushrooms are supposed to be rich sources of various pharmaceutical compounds including AMPs [14-20]. Reishi mushroom
(Ganoderma lucidum) is one of the most famous oriental mushrooms having a long history of medicinal use in China, Japan, and Asian countries. It is a large, dark mushroom with a glossy exterior and a woody texture. Among edible mushrooms, G. lucidum has more pharmaceutical values rather than nutritional values. Varieties of commercial products of this mushroom are available in the world market in the forms of powders, dietary supplements, and tea [21]. Lindequist et al. [22] have also reported the impending effects of different extracts of lingzhi on various bacterial strains. Although such medicinal properties of G. lucidum were explored to support its ancient claims, only less number of studies has been carried out on protein/peptide-based antibiotics of reishi mushroom. For example, a $45 \mathrm{kDa}$ protein isolated from G. lucidum was found to have potential antibacterial and antioxidant activities [23]. Hence, in this paper, we have discussed our investigation concerning the presence of antibacterial proteins in G. lucidum against human pathogenic bacteria.

\section{METHODS}

Collection and identification of test mushroom

The reishi mushroom (G. lucidum) was collected from a local dry land after capturing its picture. It was brought to the laboratory and manually matched with images of the list of Indian mushrooms and confirmed the same. Their properties and medicinal values were also checked with the help of appropriate articles (Fig. 1).

\section{Tissues preparation}

The fruiting body of the mushroom is slashed and washed well with tap water followed by distilled water. Appropriate weight of the tissue was taken and minced into small pieces and again washed well. Then, it was finely ground in an appropriate volume of deionized water with the help of mortar and pestle so as to prepare $10 \%(\mathrm{~W} / \mathrm{V}$ ) aqueous solution. The aqueous sample solution was stored in the refrigerator until use. 
Preparation of acid extract

The aqueous solution of $G$. lucidum was subjected to acid extraction adopting the procedure of Matutte et al. [24] with a slight modification and the acid extracted protein solution was collected in a separate sterile vial and stored in the refrigerator until use.

Precipitation of ABPs using different precipitating agents

The acid extracted proteins were precipitated using different protein precipitating reagents such as $10-50 \%$ of ammonium sulfate solutions (five concentrations), 10\% trichloroacetic acid (TCA), 80\% Ethanol and Methanol - Chloroform mixture (2:1 ratio) following the procedure of Sundaramoorthy et al. [25]

\section{Protein estimation}

The protein concentration of stepwise protein extraction of the test mushroom was estimated by adopting the procedure of Lowry et al. [26].

\section{Collection of bacterial isolates}

Seven bacterial isolates E. coli, Proteus mirabilis, Staphylococcus aureus, Klebsiella pneumoniae, Salmonella typhi, Salmonella paratyphi "A," and Pseudomonas aeruginosa procured from Microbiology Laboratory, K.A.P. Viswanatham Government Medical College, Tiruchirappalli, were sub cultured periodically and stored in glycerol semi solid media. These pure isolates were inoculated in 1\% Mueller-Hinton Agar media and incubated at $37^{\circ} \mathrm{C}$ for overnight.

\section{Antibacterial assay}

The antibacterial assay of the test samples was performed in microtiter plate using resazurin as an indicator of cell growth adopting the procedure of Sarker et al. [27]. The organisms were diluted to 200 times by $1 \%$ MHA. A sterile 96 well plate was labeled as per the protocol designed. A volume of $100 \mu$ l of test protein was pipetted out into the appropriate columns of the plate. Following this, the microwells of the respective rows were filled with $10 \mu$ of the diluted bacterial suspension $\left(5 \times 10^{6} \mathrm{CFU} / \mathrm{ml}\right)$. Finally, to each well, a $10 \mu \mathrm{l}$ of resazurin

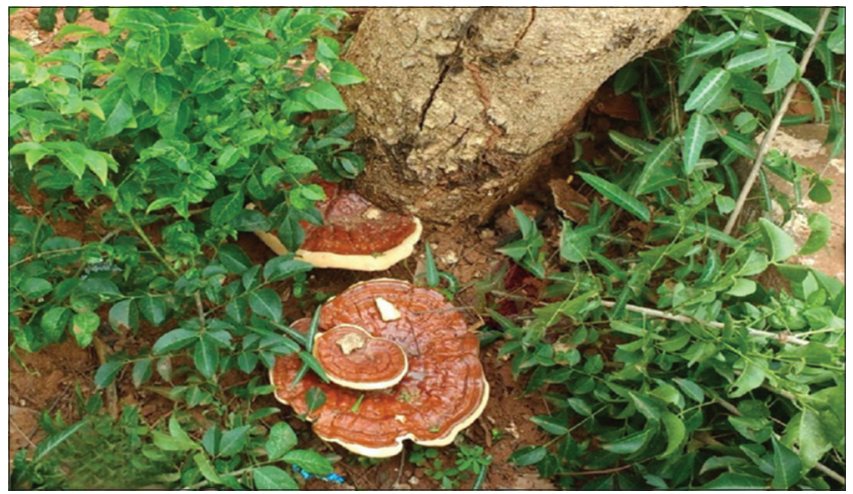

Fig. 1: Ganoderma lucidum (Test mushroom) indicator solution (270 mg resazurin diluted in $40 \mathrm{ml}$ of distilled water) was added. The plate was covered with the lid provided and incubated for $24 \mathrm{~h}$ at $37^{\circ} \mathrm{C}$. The color change was then observed visually, and the change of color from purple to pink or colorless was recorded as the presence of bacterial growth whereas the retaining of purple as such indicated the growth inhibition (Table 1). The experiments were done in triplicate for concordant results.

\section{Hemolytic assay}

The minimum hemolytic volume (MHV) of all the eight protein precipitates was carried out in a sterile microwell plate following the method of Zhu et al. [28] with a slight modification. The human blood sample was gifted by a local clinical laboratory. The sediment of red blood cells was repeatedly washed with $0.9 \% \mathrm{NaCl}$ and made into $4 \%$ suspension with normal saline. All the test wells were filled with $100 \mu$ l of normal saline. The first wells of the marked column for protein samples were filled with $100 \mu \mathrm{l}$ of the respective protein solutions and serially diluted to ensure that each first well had $50 \mu \mathrm{l}$ of the protein sample in serially descending concentration. Then, $100 \mu \mathrm{l}$ of $4 \%$ hRBCs was added in the wells of the respective rows. The $4 \%$ hRBCs alone and $4 \%$ hRBCs with $10 \%$ SDS were used as $0 \%$ (negative control) and 100\% (positive control) hemolytic controls, respectively. After $2 \mathrm{~h}$ of incubation, the button formation or color change was recorded as absence or presence of hemolysis, respectively. The MHV of a protein is defined as the lowest volume of protein at which $100 \%$ hemolysis occurs. The experiments were done in triplicate for concordant results.

Minimum inhibitory volume (MIV)

The active protein sample (10\% TCA precipitate) was chosen for MIV based on three criteria which include (i) potential bactericidal activity on all test organisms, (ii) less hemolytic effects on hRBC, and (iii) less quantity of reagent consumption for precipitating the appropriate protein. The active protein was tested for MIV for the same organisms subjected to antibacterial activity. The method adopted for MIV determination was also the same as that of antibacterial assay except for the serial dilution of the test protein solution. All the wells designed for the protocol were filled with $100 \mu \mathrm{l}$ of $1 \%$ nutrient broth. About $100 \mu \mathrm{l}$ of the protein solution was pipetted into each well of the first column of the plates marked for seven different bacterial strains. Then, a serial dilution was made to ensure that the first wells each row had $50 \mu \mathrm{l}$ of the test proteins, and the succeeding wells had half of the volume of protein solution from the previous well in serially descending concentrations. Thereafter, $10 \mu \mathrm{l}$ of bacterial suspension followed by the same volume of resazurin indicator were added in each and incubated in the same way similar to that of antibacterial assay performed adopting the method of Sarker et al. [27]. The MIV values were determined by visual observation of color change, as mentioned above. The experiments were done in triplicate for concordant results.

\section{RESULTS}

The total protein contents of the aqueous extract of G. lucidum were found to be $39.28 \mathrm{mg} /$ g.wet.wt. After acid extraction, the protein

Table 1: Antibacterial activities of proteins precipitated from acid extract of Ganoderma lucidum with different protein precipitating agents against human pathogenic bacteria

\begin{tabular}{|c|c|c|c|c|c|c|c|c|}
\hline \multirow[t]{2}{*}{$\begin{array}{l}\text { Protein precipitates } \\
\text { versus pathogens }\end{array}$} & \multicolumn{5}{|c|}{$\begin{array}{l}\text { Ammonium sulfate precipitates of } \\
\text { different percentages }\end{array}$} & \multirow[t]{2}{*}{$10 \%$ TCA } & \multirow[t]{2}{*}{$80 \%$ Ethanol } & \multirow[t]{2}{*}{ Meth-chloroform mixture (2:1) } \\
\hline & $10 \%$ & $20 \%$ & $30 \%$ & $40 \%$ & $50 \%$ & & & \\
\hline Eschereria coli & + & + & + & + & + & - & $+/-$ & $+/-$ \\
\hline Proteus mirabilis & \pm & \pm & \pm & \pm & \pm & - & \pm & \pm \\
\hline Klebsiella pneumoniae & \pm & \pm & \pm & \pm & \pm & - & \pm & \pm \\
\hline Pseudomonas aeruginosa & \pm & \pm & \pm & \pm & \pm & - & \pm & \pm \\
\hline Staphylococcus aureus & \pm & \pm & \pm & \pm & \pm & - & \pm & \pm \\
\hline Salmonella typhi & \pm & \pm & \pm & \pm & \pm & - & \pm & \pm \\
\hline Salmonella paratyphi $A$ & \pm & \pm & \pm & \pm & \pm & - & \pm & \pm \\
\hline
\end{tabular}

Interpretation: Bacterial Growth (+), Growth Inhibition (-) and Partial Growth Inhibition ( \pm ). TCA: Trichloroacetic acid 
precipitates prepared by treating with different protein precipitating agents were found in the range of 2.3-4.8 mg/g.wet.wt. and the peak amount of protein ( $4.8 \mathrm{mg} /$ g.wet.wt) was obtained by $10 \%$ TCA precipitation (Fig. 2).

Table 1 reveals the antibacterial activity of different protein precipitates obtained from the acid extract of test mushroom. The growth of all test organisms except E. coli was found susceptible in partial or whole by the test proteins. However, the 10\% TCA precipitate exhibited a strong growth inhibition on all test bacteria.

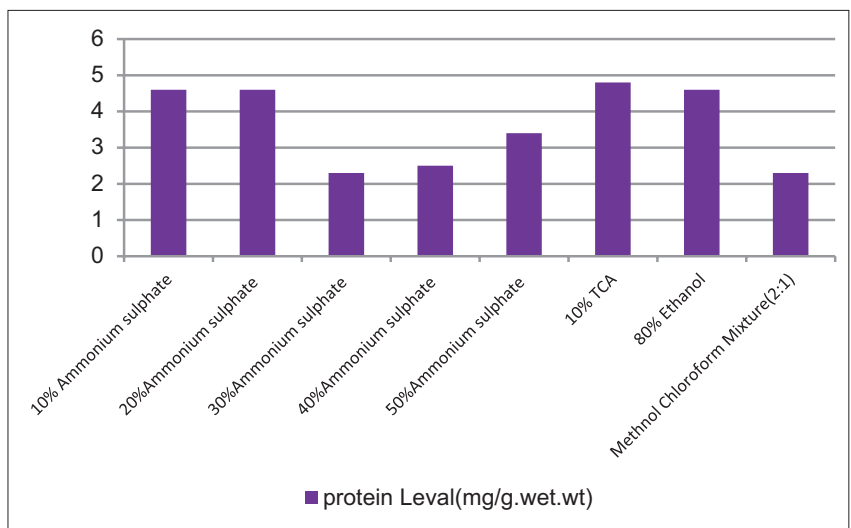

Fig. 2: The quantity of proteins precipitated from the acid extract of Ganoderma lucidum by different protein precipitating reagents

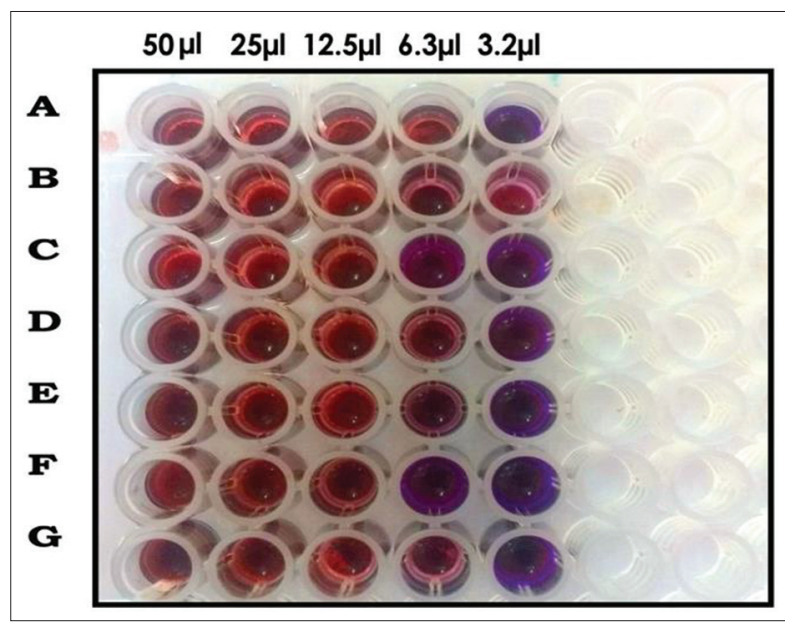

Fig. 3: Minimum inhibitory volume of active protein solution of Ganoderma lucidum (10\% trichloroacetic acid precipitate prepared from acid extract). The alphabets A-G represents the test bacteria Escherichia coli, Proteus mirabilis, Klebsiella pneumoniae, Staphylococcus aureus, Salmonella typhi, Salmonella paratyphi " $A$," respectively
Table 2 shows the MHV of the protein precipitates on hRBCs. Protein precipitates obtained by $10-40 \%$ ammonium sulfate solution caused severe hemolysis even at the lowest volume of protein solution $(1.56 \mu \mathrm{l})$ where the remaining four protein precipitates exhibited no hemolytic effects up to the higher volume of $12.5 \mu$ l.

Describing together the antibacterial and hemolytic activities of eight different protein precipitates, the 10\% TCA precipitate showed a strong bactericidal activity without hemolytic effects, and hence it was chosen as active protein precipitate and subjected for MIV assay. In which, the last two minimum volumes of TCA precipitates ( 6.3 and $3.2 \mu$ ) have exhibited potential bactericidal activities on all test organisms, as shown in Fig. 3.

The pink color denotes the bacterial growth whereas the blue color denotes the growth inhibition.

\section{DISCUSSION}

The health benefits of different mushroom species have been documented many decades ago. A few literatures in this regard have been addressed here. Antioxidant, antimicrobial, and antiproliferative activities of Agaricus sp. and Cantharel luscibarus have been studied [29,30]. In earlier years, it was thought that the compounds responsible for the bioactivities might be only secondary metabolites. Later studies have shown that certain higher molecular weight peptides and proteins of mushroom species are also taking part in bioactivity. Various antifungal proteins from different fungi such as Clitocybe sinopica, Aspergillus giganteus, Aspergillus niger, Zygosaccharomyces bailii, and Tricholoma giganteum [19,31-34] have been reported. An immune modulatory protein LZ-8 from G. lucidum was also proposed to have therapeutic effects on cancer and autoimmune disease [35]. Subsequent to this finding, in the present work, the presence of antibacterial proteins in the acid extract of the mushroom, G. lucidum was verified using different protein precipitating agents.

The total protein content of the aqueous extract of the test mushroom, G. lucidum was found to be $39.28 \mathrm{mg} / \mathrm{g}$.wet.wt. This quantity is significantly relevant to the range of other mushroom (Pleurotus ostreatus, Volvariella volvacea, Agaricus campestris, and T. Hemii) protein levels, i.e., 33-38\% [36]. The antibacterial proteins precipitated by different protein precipitating agents from the acid extract were found in the range of $2.3-4.8 \mathrm{mg} / \mathrm{g}$.wet.wt. Among the precipitates, $10 \%$ TCA solution has yielded the highest quantity of protein precipitates ( $4.8 \mathrm{mg} /$ g.wet.wt), as shown in Fig. 2.

Table 1 revealed the antibacterial activity of these protein precipitates. Except for the growth of E. coli, all other organisms' growth has been inhibited by the test proteins at different levels. However, the 10\% TCA precipitate has exhibited a strong growth inhibition on all test bacteria. The presence of antimicrobial proteins in mushrooms and fungus is in agreement with some previous studies. Antifungal proteins and peptides have been isolated from diverse fungal species [31-33,37]. A mixture of antibacterial proteins against Gram-positive and negative bacteria

Table 2: Minimum hemolytic volume of proteins precipitated from acid extract of Ganoderma lucidum with different protein precipitating agents

\begin{tabular}{|c|c|c|c|c|c|c|c|c|c|}
\hline \multicolumn{2}{|c|}{ Concentration of protein precipitates versus hemolysis } & \multirow{2}{*}{$\frac{50 \mu \mathbf{l}}{\mathrm{H}^{+}}$} & \multirow{2}{*}{$\frac{25 \mu \mathrm{l}}{\mathrm{H}^{+}}$} & \multirow{2}{*}{$\frac{12.50 \mu \mathrm{l}}{\mathrm{PH}^{+}}$} & \multirow{2}{*}{$\begin{array}{l}6.25 \mu \mathrm{l} \\
\mathrm{H}^{+}\end{array}$} & \multirow{2}{*}{$\begin{array}{l}3.12 \mu \mathrm{l} \\
\mathrm{H}^{+}\end{array}$} & \multirow{2}{*}{$\begin{array}{l}1.56 \mu l \\
\mathrm{H}^{-}\end{array}$} & \multirow{2}{*}{$\frac{\mathrm{C1}}{\mathrm{H}^{-}}$} & \multirow{2}{*}{$\frac{\mathrm{C} 2}{\mathrm{H}^{+}}$} \\
\hline Ammonium sulfate precipitates at different & 10 & & & & & & & & \\
\hline percentages (\%) & 20 & $\mathrm{H}^{+}$ & $\mathrm{H}^{+}$ & $\mathrm{PH}^{+}$ & $\mathrm{PH}^{+}$ & $\mathrm{H}^{+}$ & $\mathrm{H}^{-}$ & $\mathrm{H}^{-}$ & $\mathrm{H}^{+}$ \\
\hline & 30 & $\mathrm{H}^{+}$ & $\mathrm{H}^{+}$ & $\mathrm{PH}^{+}$ & $\mathrm{PH}^{+}$ & $\mathrm{H}^{+}$ & $\mathrm{H}^{-}$ & $\mathrm{H}^{-}$ & $\mathrm{H}^{+}$ \\
\hline & 40 & $\mathrm{H}^{+}$ & $\mathrm{H}^{+}$ & $\mathrm{H}^{-}$ & $\mathrm{H}^{+}$ & $\mathrm{H}^{+}$ & $\mathrm{H}^{-}$ & $\mathrm{H}^{-}$ & $\mathrm{H}^{+}$ \\
\hline & 50 & $\mathrm{H}^{+}$ & $\mathrm{H}^{+}$ & $\mathrm{H}^{-}$ & $\mathrm{H}^{-}$ & $\mathrm{H}^{-}$ & $\mathrm{H}^{-}$ & $\mathrm{H}^{-}$ & $\mathrm{H}^{+}$ \\
\hline TCA 10\% & & $\mathrm{PH}^{+}$ & $\mathrm{PH}^{+}$ & $\mathrm{H}^{-}$ & $\mathrm{H}^{-}$ & $\mathrm{H}^{-}$ & $\mathrm{H}^{-}$ & $\mathrm{H}^{-}$ & $\mathrm{H}^{+}$ \\
\hline Ethanol 80\% & & $\mathrm{PH}^{+}$ & $\mathrm{PH}^{+}$ & $\mathrm{H}^{-}$ & $\mathrm{H}^{-}$ & $\mathrm{H}^{-}$ & $\mathrm{H}^{-}$ & $\mathrm{H}^{-}$ & $\mathrm{H}^{+}$ \\
\hline
\end{tabular}

Interpretation: Hemolysis $\left(\mathrm{H}^{+}\right)$, Absence of hemolysis $\left(\mathrm{H}^{-}\right)$, Partial Hemolysis $\left(\mathrm{PH}^{+}\right)$, $\mathrm{C} 1$ - (Negative Control - 0\% Hemolysis) and $\mathrm{C} 2-(\mathrm{Positive}$ Control - $100 \%$

Hemolysis). TCA: Trichloroacetic acid 
was extracted from white button mushroom (Agaricus bisporus) using ultrasonication technique by Kavitha and Damodharan [38]. A protein bound polysaccharide called polysaccharopeptide, exhibiting strong antimicrobial activity has also been isolated from Coriolus versicolor fungi [39].

The 10\% TCA precipitate of the test mushroom chosen for MIV had potential bactericidal activities on test organisms at two minimum volumes, as shown in Fig. 3 (6.3 and $3.2 \mu \mathrm{l})$. Similarly, the bacterial growth inhibition at micromolar concentration of different mushroom AMPs has also been investigated earlier. For instance, the proteins purified from Clitocybe sinopica had potential antifungal activity toward Agrobacterium tumefaciens at 0.14-2.7 $\mu \mathrm{M}$ [19]. These proteins had also a broad spectrum of activities against a number of plant pathogenic bacteria including strains of Agrobacterium and Xanthomonas.

Although the AMPs isolated from natural sources like mushrooms have a potential killing capacity of different pathogens, most of them present toxic effects to the host cells. Unless making some essential modifications in their sequences, their toxicity could not be prevented or reduced. Instance, fowlicidins $(-1$ and -2$)$ of chicken displayed potent salt-independent activities against a range of Gram-negative and Gram-positive bacteria, including antibiotic-resistant strains with hemolytic property [40]. The hemolytic activity of both fowlicidins was reduced significantly by $10 \%$ PBS. Similarly, Trp/Pro-rich short peptides consisting only 13 residues such as tritrpticin and indolicidin having a broad spectrum of antimicrobial activities showed relative toxicity toward eukaryotic cells. Hence, much effort has been taken to decrease the cytotoxicity and to increase the cell selectivity of these two peptides [41,42]. Auspiciously, the test proteins of $G$. lucidum have exhibited less toxicity on hRBCs. The test proteins yielded by 40 and 50\% ammonium sulfate, 10\% TCA and 80 Ethanol, and Methanol - Chloroform mixture were found to be nontoxic to the human erythrocytes from $1.6 \mu \mathrm{l}$ to $12.5 \mu \mathrm{l}$. The higher volumes caused distinct hemolysis, as found in Table 2.

The active protein precipitate showed strong antibacterial activity at the lowest volume of protein solution subjected $(3.2 \mu \mathrm{l})$ and not in higher volumes (Fig. 3). Logically, the drug concentration and level of bioactivity should be in the same line. However, it is found contradictory in this study. Although the exact reason for this is not known, this might be due to the mode action of the protein sequence. In the lower concentration, the protein sequence would be completely open, and the active domain could be accessible to act with the receptor molecule of the bacterial cell wall. In case of a higher concentration, the sequential crowd would lead several folding and which may hide the active site not to act with the receptor. In contrast to the bactericidal capacity, the lowest volume of the test protein, i.e. $1.6 \mu \mathrm{l}$ showed no hemolysis. Hence, further deep studies in this regard could help to develop them as drug candidates by solving the above-discussed problem. The development of such natural antibiotics could also be affordable in the pharmaceutical market.

\section{CONCLUSION}

It is well-known fact that mushrooms have plenty of medicinal properties with their secondary metabolites. However, the study on antimicrobial properties of mushroom proteins is still infancy. In this circumstance, this study has substantiated that the protein precipitated by $10 \%$ TCA from the acid extract of the mushroom, G. lucidum has strong antibacterial effects against human pathogenic bacteria with less hemolytic effects. Hence, this protein precipitate could be considered for the development of natural antibiotics after kind enough further studies.

\section{ACKNOWLEDGMENT}

We wish to thank Tamil Nadu State Council for Higher Education for its financial support under the scheme of the minor project for college teachers and also we extend our thanks to the medical professionals of Microbiology Laboratory, K.A.P.Viswanatham Government Medical College, Tiruchirappalli, for rendering pure culture of bacterial strains.

\section{AUTHORS' CONTRIBUTIONS}

The first author's contributions are work idea, execution of the work plan, the arrangement of materials, and drafting the manuscript. The second author carried out experiments.

\section{CONFLICTS OF INTEREST}

Authors declare that they have no conflicts of interest.

\section{REFERENCES}

1. Harbarth S, Harris AD, Carmeli Y, Samore MH. Parallel analysis of individual and aggregated data on antibiotic exposure and resistance in gram negative bacilli. Clin Infect Dis 2001:33:1462-8.

2. Segal-Maurer S, Urban C, Rahal JJ Jr. Current perspectives on multidrug-resistant bacteria. Epidemiology and control. Infect Dis Clin North Am 1996;10:939-57.

3. Hamid IS, Eltayeb IM. In vitro susceptibility of Shigella flexneri and Shigella dysenteriae to the ethanolic extracts of Trachysperum ammi and Peganum harmala. Int J Pharm Pharm Sci 2019;11:103-6.

4. Dahham SS, Hew CS, Jaafar I, Gam LH. The protein profiling of Asian giant toad skin secretions and their antimicrobial activity. Int J Pharm Pharm Sci 2016;8:88-95

5. Sundaramoorthy M, Saravanan TS. Antibacterial effects of goat and chicken heart tissues against human pathogenic bacteria. Indian J Exp Biol 2010;48:407-14.

6. Daher KA, Selsted ME, Lehrer RI. Direct inactivation of viruses by human granulocyte defensins. J Virol 1986;60:1068-74.

7. Diamond G, Zasloff M, Eck H, Brasseur M, Maloy WL, Bevins CL, et al. Tracheal antimicrobial peptide, a cysteine-rich peptide from mammalian tracheal mucosa: Peptide isolation and cloning of a cDNA. Proc Natl Acad Sci U S A 1991;88:3952-6.

8. Selsted ME, Tang YQ, Morris WL, McGuire PA, Novotny MJ, Smith W, et al. Purification, primary structures, and antibacterial activities of beta-defensins, a new family of antimicrobial peptides from bovine neutrophils. J Biol Chem 1993;268:6641-8.

9. Harder J, Bartels J, Christophers E, Schröder JM. A peptide antibiotic from human skin. Nature 1997;387:861.

10. Rinaldi AC. Antimicrobial peptides from amphibian skin: An expanding scenario. Curr Opin Chem Biol 2002;6:799-804.

11. Sundaramoorthy M, Saravanan TS. A natural antibacterial peptide from goat heart tissues against S. typhi and P. aeruginosa. World J Zool 2011;6:227-34

12. Sundaramoorthy M, Saravanan TS. Purification of an antibactierial peptide from chicken heart tissues by RP- HPLC against Pseudomonas aeruginosa. Int J Sci Nat 2011;2:310-6.

13. Sundaramoorthy M, Gomathi S, Kannaki S, Saravanan TS. Antibacterial and haemolytic activities of tissue proteins of the major carp, Labeo Rohita (Hamilton). Int J Sci Nat 2011:2:671-6.

14. Zaiou YT, Gallo R. Some bioactive properties of wild and commercial mushroom species. J Food Health Sci 2002;3:161-9.

15. Bals R. Wild and commercial mushrooms as source of nutrients and nutraceuticals. Food Chem Toxicol 1998;46:2742-7.

16. Houshdar Tehrani MH, Fakhrehoseini E, Kamali Nejad M, Mehregan H, Hakemi-Vala M. Search for proteins in the liquid extract of edible mushroom, Agaricus bisporus, and studying their antibacterial effects. Iran J Pharm Res 2012;11:145-50.

17. Pouchert P, Fons F, Raiors S. Biological and pharmacological activity of higher fungi 20-year retrospective analysis. Mycologie 2006;27:311-33.

18. Öztürk M, Duru ME, Kivrak S, Mercan-Doğan N, TürkogluA, Özler MA, et al. In vitro antioxidant, anticholinesterase and antimicrobial activity studies on three Agaricus species with fatty acid compositions and iron contents: A comparative study on the three most edible mushrooms. Food Chem Toxicol 2011;49:1353-60.

19. Zheng S, Liu Q, Zhang G, Wang H, Ng TB. Purification and characterization of an antibacterial protein from dried fruiting bodies of the wild mushroom Clitocybe sinopica. Acta Biochim Pol 2010;57:43-8.

20. Hearst M, Nelson D, McCollum G, Linda M, Ballard B, Moore S, et al. Antimicrobial properties of protein extracts from wild mushroom fungi and native plant species against hospital pathogens. J Pharmacogn Phytother 2010;2:103-7.

21. Wasser SP. Reishi or Lingzhi (Ganoderma lucidum) In: Encyclopedia of Dietary Supplements. New York: Marcel Decker; 2005. p. 603-20.

22. Lindequist U, Niedermeyer TH, Jülich WD. The pharmacological potential of mushrooms. Evid Based Complement Alternat Med 2005;2:285-99. 
23. Sa-Ard P, Sarnthima R, Khammuang S, Kanchanarach W. Antioxidant, antibacterial and DNA protective activities of protein extracts from Ganoderma lucidum. J Food Sci Technol 2015;52:2966-73.

24. Matutte B, Storey KB, Knoop FC, Conlon JM. Induction of synthesis of an antimicrobial peptide in the skin of the freeze-tolerant frog, Rana sylvatica, in response to environmental stimuli. FEBS Lett 2000;483:135-8.

25. Sundaramoorthy M, Deepa K, Saravanan TS. Chemical preparation of bioactive protein from cow heart tissues: An evaluation. Int J Adv Res Biotech 2012;1:18-21

26. Lowry OH, Rosebrough NJ, Farr AL, Randall RJ. Protein measurement with the folin phenol reagent. J Biol Chem 1951;193:265-75.

27. Sarker SD, Nahar L, Kumarasamy Y. Microtitre plate-based antibacterial assay incorporating resazurin as an indicator of cell growth, and its application in the in vitro antibacterial screening of phytochemicals. Methods 2007;42:321-4.

28. Zhu WL, Hahm KS, Shin SY. Cathelicidin-derived trp/Pro-rich antimicrobial peptides with lysine peptoid residue (Nlys): Therapeutic index and plausible mode of action. J Pept Sci 2007;13:529-35

29. Jagadesh LK, Krishnan V, Shenbhagaraman R Kaviyarasan V. Comparative study on the antioxidant, anticancer and antimicrobial property of Agaricus bisporus (J.E Lange) Imbach before and after boiling. Afr J Biotechnol 2009;8:654-61.

30. Ramesh Ch, Pattar MG. Antimicrobial properties, antioxidant activity and bioactive compounds from six wild edible mushrooms of Western Ghats of Karnataka, India. Pharmacognosy Res 2010;2:107-12.

31. Lacadena J, Martínez del Pozo A, Gasset M, Patiño B, Campos-Olivas R, Vázquez $\mathrm{C}$, et al. Characterization of the antifungal protein secreted by the mould Aspergillus giganteus. Arch Biochem Biophys 1995;324:27381.

32. Lee DG, Shin SY, Maeng CY, Jin ZZ, Kim KL, Hahm KS, et al.
Isolation and characterization of a novel antifungal peptide from Aspergillus niger. Biochem Biophys Res Commun 1999;263:646-51.

33. Weiler F, Schmitt MJ. Zygocin, a secreted antifungal toxin of the yeast Zygosaccharomyces bailii, and its effect on sensitive fungal cells. FEMS Yeast Res 2003;3:69-76.

34. Guo Y, Wang $\mathrm{H}, \mathrm{Ng} \mathrm{TB}$. Isolation of trichogin, an antifungal protein from fresh fruiting bodies of the edible mushroom Tricholoma giganteum. Peptides 2005;26:575-80.

35. Xue Q, Ding Y, Shang C, Jiang C, Zhao M. Functional expression of LZ-8, a fungal immunomodulatory protein from Ganoderma lucidium in Pichia pastoris. J Gen Appl Microbiol 2008;54:393-8.

36. Singha SS, Soltnian H, Razaenin A, Janpoor S. Antibactrial activity of crude extract and fractions from Iranian wild-grown and cultivation. Biomed Res 2017;27:56-9.

37. Lam SK, Ng TB. First simultaneous isolation of a ribosome inactivating protein and an antifungal protein from a mushroom (Lyophyllum shimeji) together with evidence for synergism of their antifungal effects. Arch Biochem Biophys 2001;393:271-80.

38. Kavitha R, Damodharan N. Ultrasonic assisted extraction and antibacterial activities of protein recovered from white Button Mushroom Agaricus bisporus. Int J PharmTech Res 2015;8:991-5.

39. Coban EP, Isman B, Biyik HH. Effects of Protein bound polysaccharide against some microorganism. Turk Mikrobial Cem Derg 2008;38:150-5.

40. Xiao Y, Dai H, Bommineni YR, Soulages JL, Gong YX, Prakash O, et al. Structure-activity relationships of fowlicidin-1, a cathelicidin antimicrobial peptide in chicken. FEBS J 2006;273:2581-93.

41. Falla TJ, Karunaratne DN, Hancock RE. Mode of action of the antimicrobial peptide indolicidin. J Biol Chem 1996;271:19298-303.

42. Yang ST, Shin SY, Kim Y, Comformation dependent antimicrobial peptide. Biochem Biophys Res Commun 2002;296:1044-105. 